\title{
Spatial influence on qualitative food consumption in Colombia
}

\author{
Influência espacial sobre o consumo alimentar qualitativo \\ em Colômbia
}

Diana E. Forero Rodríguez (https://orcid.org/0000-0001-9358-0750) ${ }^{1}$

Milena Lima de Moraes (https://orcid.org/0000-0003-1222-8400) ${ }^{2}$

\footnotetext{
${ }^{1}$ Escuela de Administración de Empresas y Contaduría

Pública, Facultad de

Ciencias Económicas

y Administrativas,

Universidad Nacional de

Colombia. Carrera 30 No 45

03. Bogotá D.C. Colombia.

deforeror@unal.edu.co.

${ }^{2}$ Departamento de

Nutrición Humana,

Facultad de Medicina,

Universidad Nacional de

Colombia. Bogotá D.C.

Colombia.
}

\begin{abstract}
Spatial location is a factor that may facilitate the consumption of processed foods due to the ease of access, especially in highly urbanized, high density populations. This study presents the differences in food consumption in populations with different densities and urban and rural characteristics, and income above and below ten dollars a day. A sample of 2,130 subjects was used from 9 populations that included the Capital of Colombia, outlying medium-sized municipalities, metropolitan-area municipalities and small villages. The results confirm that processed and ultra-processed foods are consumed more in cities and urban areas than in smaller and rural populations, and that there are differences in consumption generated by income.
\end{abstract}

Key words Food consumption, Colombia, Spatial analysis
Resumo A localização espacial é um fator que pode facilitar o consumo de alimentos processados devido à facilidade de acesso, principalmente em populações altamente urbanizadas e com alta densidade populacional. Este estudo apresenta as diferenças no consumo alimentar em populações com diferentes densidades, características urbanas e rurais e renda maior ou menor de 10 dólares. A amostra foi de 2.130 individuos em 9 populações que incluíam a capital da Colômbia, municípios médios próximos à capital, municípios da área metropolitana e cidades rurais pequenas. Os resultados confirmam que os alimentos processados e ultraprocessados são mais consumidos nas cidades e áreas urbanas em relação aos municípios rurais e pequenos, além disso há diferenças no consumo geradas pela renda.

Palavras-chave Consumo de alimentos, Colômbia, Análise espacial 


\section{Introduction}

Globalization with its focus on technology, goods and services has had profound effects on the lifestyles of populations in terms of food. The commercialization of fresh food in farmers' markets is disappearing as the main source of food supplies. These markets are being replaced by multinational, regional and local supermarkets that are often part of larger chains ${ }^{1,2}$.

This change leads to shifts in food consumption that show a tendency to be increasingly dense in energy. This, in part due to the fact that fresh foods that generally contain a greater supply of fibers and micronutrients are being replaced by processed and ultra-processed foods containing high quantities of salt, saturated fats, trans fats, refined sugars, calories and reduced amounts of fiber and micronutrients $s^{3,4}$. In addition, there has also been an increase in the size of portions of food, especially processed and ultra-processed foods. This has been accompanied by low physical activity that has had a significant impact on the health of the population. In fact, this has led to an increase in the prevalence of non-communicable diseases (NCD), which are currently the leading causes of death in the world ${ }^{1,5}$. Therefore, high consumption of ultra-processed and processed foods is already recognized as a risk factor for $\mathrm{NCD}^{3}$.

In today's globalized context, evidence of a direct correlation between food consumption and environmental conditions is increasing ${ }^{6-9}$. In this scenario, spatial location and population density of where people live are important food environment factors due to their influence on food availability and affordability. These, therefore, can affect the kind of food consumed in households ${ }^{6-8,10}$. In countries with different income levels was observed that unaffordability of fresh food as fruits and vegetables was higher in rural and less densely populated areas than in urban and more densely populated areas. Also, rural area residents use to have lower income. At the same time income levels are decisive to kind of food consumed and unfortunately it is necessary higher income in rural area than urban area to consume fruits and vegetables according recommendation from several international guidelines - five servings per day ${ }^{11}$. The result of unaffordability of fresh food due increased cost of food is reduction in the quantity, quality, and diversity of food selections, and consumption of increased quantities of cheap, energy-dense foods as processed and ultra-processed foods ${ }^{12}$.
Cundinamarca is a state that has municipalities of different sizes and population density. In this territory is the capital of the country but also a small municipality. Even with mountainous geography, the distribution of food is carried out by country mostly by poor rural and urban road, configuring a scarce food distribution infrastructure, mainly to fresh food ${ }^{13}$.

In view of the above, the objective of this study was to analyze the qualitative food consumption of representative population samples of Colombia's capital city, some municipalities and villages with different population sizes and geographic locations (rural and urban in Cundinamarca) in order to analyze if there are differences in qualitative food consumption in these areas, taking into account different income levels.

\section{Methods}

\section{Study location, population and demography}

For the geographic location and population, we used information from the National Administrative Department of Statistics of Colombia $(\mathrm{DANE})^{14}$. So, a representative population sample of 2,130 people from Bogotá D.C. and eight municipalities from the Cundinamarca Department, Colombia were enrolled in this study and interviewed. These municipalities were classified into four municipality categories according to their rural or urban characteristics and geographic location relative to the capital city in: 1) Capital city (Bogotá D.C., capital of Colombia with 7,980,000 inhabitants) which is the biggest city in the country and has mainly urban characteristics; 2) outlying medium-sized municipalities (Facatativá and Girardot, which are located further from the capital city, with 135,522 and 105.701 inhabitants, respectively) those have urban-rural characteristics; 3) metropolitan-area municipalities (Soacha, Chía and Ubaté, all of which comprise the metropolitan area along with Bogotá, with 522,442, 129,625 and 39,018 inhabitants, respectively) those have urban-rural characteristics and; 4) small villages (Pacho, Bituima and Villagómez, which are located further from the capital city with $27,388,2,508$ and 2,176 inhabitants, respectively) those have rural characteristics. In these rural municipalities, the questionnaires were applied in the areas where the majority of the municipality's population is concentrated, not in dispersed rural areas. In all 
Probabilistic multi-stage sampling was used and achieved a sampling error of 0.021 with $95 \%$ confidence interval (CI). The enrolled subjects were invited to answer a questionnaire applied by a trained interviewer. The principal investigator was responsible for training all interviewers. The survey was conducted at the domicile of the interviewees. The interview was conducted with an adult, family member. The adult who responded was responsible for the children's care from their family or other families (in Colombia, it is common that neighbors take care of children from other neighbors). Families with pregnant women were included. Households had different family compositions (with different age groups), however, homes where an adult was not present and homes where a child caregiver was not found were excluded. Sociodemographic and income information was self-reported by the informant. The questionnaire was a survey-type and had two sections. The first section included the consent form to participate in the study, sociodemographic characteristics and family features such as age, sex,

income, family size and composition. The second one was an adaptation of the food consumption frequency questionnaire used in the National Survey of the Nutritional Situation of Colombia in order to gather information about food commonly consumed in this country. In addition to this National Survey, we asked about the qualitative food consumption during the previous day using a food list from the questionnaire. The adaptation consisted in asking exclusively about qualitative food consumption without asking about consumption frequency. The questions were asked exactly as recorded in the National Survey of Nutrition about the following foods: milk, dairy, eggs, processed meat (such as sausage, ham and mortadella), legumes (such as bean, chickpea, lentil), cereals (such as rice and pasta, bread, cookies and arepas), fruit juice, whole fruit, junk foods (such as pizza, hamburger, hot dog, taco), beverage with zero calories (coffee and tea), package snacks and low calorie or dietetic foods. We grouped the food groups as follows: red meat, chicken and fish were grouped as animal protein; tubercles and plantain as tubercles; cooked and raw vegetables were grouped as vegetables; Bienestarina ${ }^{\circledR}$ (vegetable mix produced by an entity of the Colombian government and distributed to vulnerable populations) and other vegetable mixes were grouped as vegetable mixes; sweeteners (sugar, honey, panela - typical food from sugarcane) and sweetmeats were grouped as sugars. We ungrouped the food

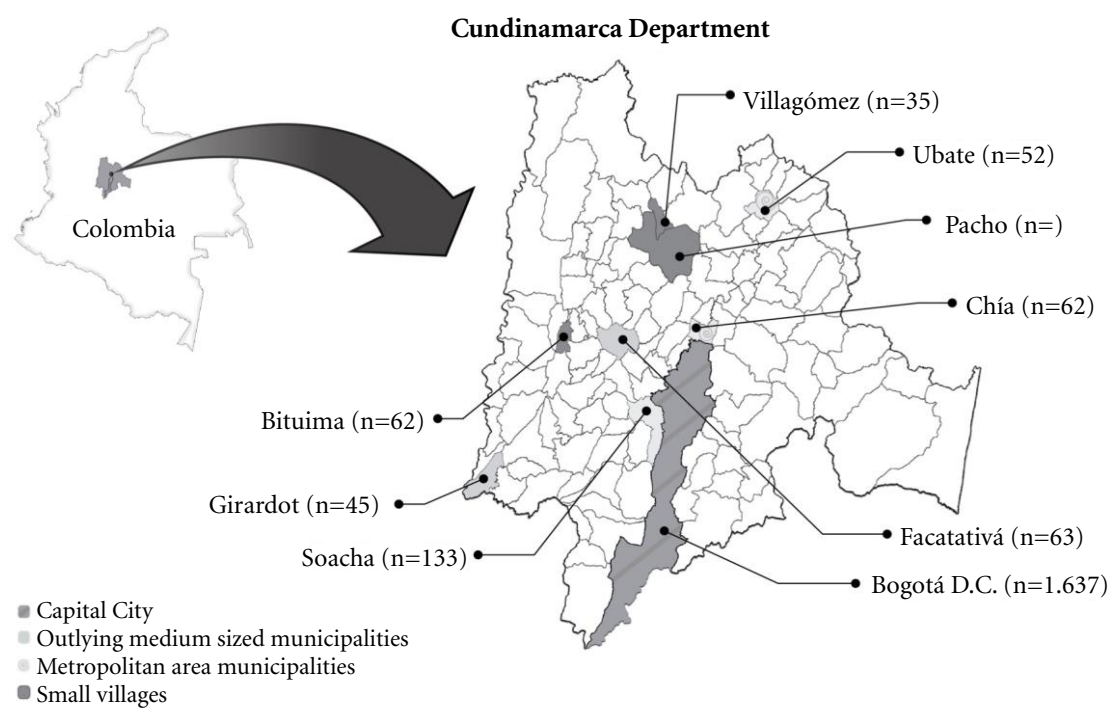

Figure 1. Distribution of municipalities and their representative population samples. 
groups as follows: sweetened beverages in carbonated sweetened beverages (soft drinks) and traditional sweetened beverages (chocolate drink and panela drink). We additionally asked about the consumption of ice cream and alcoholic beverages. The independent variable from this study was the qualitative food consumption.

\section{Statistical analysis}

The data were entered using Epi Info (Centers for Disease Control and Prevention, Atlanta, Georgia), and validated by a second person by cross-matching the database. The data are presented as mean and standard deviation or as a proportion of their percentage. The study variables were compared using ANOVA (to evaluate age and family size) and when it presented significative results, Sheffer post-hoc test was done, $\chi^{2}$ test with Fisher exact test (to evaluate income and family composition), and logistic regression were utilized to evaluate the relationship between different kinds of food consumption and two variables, the four categories of municipalities (explained above) and the income (more or less than ten dollars a day). A logistic regression model of proportional odds was used to estimate odds ratios (OR) and respective confidence intervals $(95 \% \mathrm{CI})$, and standardized residuals of the Chi square test were used to identify the foods in which there was a significant difference in the probabilities of consumption according to income. All analyses were conducted using the Statistical Package for Social Sciences (SPSS). P values $<0.05$ were considered statistically significant.

\section{Ethics approval}

This study complied with all the ethical precepts of research on human beings and was approved by the Research Ethics Committee of Konrad Lorenz University, Bogotá, Colombia.

\section{Results}

A total of 2,130 subjects were enrolled in the study. There were fewer female participants in small villages and outlying medium-size municipalities and incomes $<\$ 10$ per day were more frequent in these municipalities. In small villages, the participants were a little older than participants from the Capital city. There was no significant difference related to family composition and family size between municipalities (Table 1).
Analyzing the results from qualitative food consumption percentages and logistic regression model adjusted for income (Table 2) a similar consumption of legumes, vegetables and vegetable mixes was observed in the four categories of municipalities.

There was more likelihood to consume from the following food groups in all other municipality categories compared to small villages: dairy products, processed meat, cereals, whole fruit and sugar.

There was a greater likelihood of consumption of the following food groups in two municipality categories compared to small villages: packaged snacks, junk food, ice cream and low calories or dietetic foods in Capital city and outlying medium-sized municipalities. There was less likelihood of consumption of alcoholic beverages in metropolitan area municipalities and greater likelihood of consumption in outlying medium-sized municipalities than in small villages.

There was a greater likelihood of consumption of the following food groups in one municipality category compared to small villages: milk, eggs, animal protein and tubercles in metropolitan-area municipalities, fruit juice, traditional sweetened beverages, carbonated sweetened beverages and beverages with zero calories in outlying medium-sized municipalities. There was less likelihood of consumption of eggs in outlying medium-sized municipalities than in small villages.

Additionally, in the group with incomes $<$ US10 per day, it was observed that there was more likelihood to consume cereals, traditional sweetened beverages and vegetable mixes and less likelihood to consume animal protein and vegetables in higher income groups (Table 2 and Figure 2). The greatest differences are found in the consumption of mixed vegetables, $(\sigma=-2.3)$, where there is low consumption in the population with the highest incomes.

\section{Discussion}

The present study evaluated four municipality categories according to their rural or urban characteristics and geographic location relative to the Capital city. It was observed that in small villages, the participants were a little older than participants from the Capital city, this is due to the aging phenomenon in rural areas owing to the migration of younger citizens to urban areas ${ }^{15}$. However, despite the statistical difference, all enrolled in the study were young and middle-aged adults. 
Table 1. Socio-demographic characteristics from studied sample.

\begin{tabular}{|c|c|c|c|c|c|}
\hline Features & $\begin{array}{c}\text { Small } \\
\text { villages }\end{array}$ & $\begin{array}{l}\text { Capital } \\
\text { city }\end{array}$ & $\begin{array}{l}\text { Outlying medium } \\
\text { sized municipalities }\end{array}$ & $\begin{array}{c}\text { Metropolitan area } \\
\text { municipalities }\end{array}$ & p-value \\
\hline \multicolumn{6}{|l|}{ Demography } \\
\hline Age in years, mean $(S D)$ & $40.3(14,8)$ & $36.3(13.9)$ & $38.4(12.11)$ & $36.8(15.6)$ & $0.021^{\mathrm{a}}$ \\
\hline Female $(\%)$ & 50.0 & 63.3 & 58.3 & 71.3 & 0.00 \\
\hline \multicolumn{6}{|l|}{ Income } \\
\hline$<\$ 10$ per day $(\%)$ & 82.6 & 65.0 & 83.0 & 65.5 & 0.00 \\
\hline$>\$ 10$ per day $(\%)$ & 17.4 & 35.0 & 17.0 & 34.5 & \\
\hline \multicolumn{6}{|l|}{ Family composition } \\
\hline Only adults (\%) & 37.6 & 34.7 & 31.4 & 33.7 & 0.06 \\
\hline Adults with children (\%) & 62.4 & 65.3 & 68.6 & 66.3 & \\
\hline Family size, mean (SD) & $2.72(1.80)$ & $3.1(1.7)$ & $2.98(1.62)$ & $3.17(1.57)$ & 0.08 \\
\hline
\end{tabular}

SD: standard deviation. ${ }^{a}$ Difference between small villages and Capital city.

Source: Elaborated by the authors.

The idea that spatial location increases the risk of consumption of certain types of food is reinforced by this study. Previous studies had observed similar results ${ }^{11,16-18}$. Out of a total of 21 food groups, 18 were less likely to be consumed in small villages. This finding points to a less diversified food consumption in small villages.

Currently, it is well supported in the literature that income levels have an important influence on quality, quantity and variety of food consumed. Even in the same area (rural or urban, more or less densely populated) income levels can produce different kinds of food consumption. Additionally, it is relevant to consider that rural residents use to be poorer than urban residents and then is crucial evaluate food consumption differences clustering income levels ${ }^{11}$.

The groups of dairy products, processed meat, sugar, packaged snacks, junk food, carbonated sweetened beverages, ice cream, beverages with zero calories and low calories or dietetic foods are classified as processed or ultra-processed foods $s^{3,4}$, and all of them were more likely to be consumed in the capital city, outlying medium-sized municipalities and/or metropolitan-area municipalities than in small villages, which means in municipalities with urban characteristics. It is possible that retaining traditional diets and food patterns in general collaborate in the less likelihood of consumption of those processed or ultra-processed foods in small villages. Even so, we cannot disregard the strenuous efforts undertaken over recent decades by transnational food and drink corporations to ensure penetration of their products into rural areas, and to hope that just pushing traditional diets will be enough to maintain this pattern of consumption, are naïve ${ }^{19,20}$. For example, in the present study, fruit juices, traditional sweetened beverages, alcoholic beverages and carbonated sweetened beverages were more likely to be consumed in outlying medium-sized municipalities, which are located further away from the main urban centers characterizing the expansion of consumption of this type of industrialized drink concomitant to the maintenance of the consumption of traditional drinks.

The egg group was also less likely to be consumed in outlying medium-sized municipalities and more likely to be consumed in Capital city and metropolitan areas, the levels of egg consumption (grams per capita per day) have doubled worldwide, with the increases most marked in low and middle-income countries, such as Colombia, compared with high-income countries ${ }^{21}$.

At the same time, whole fruits, which are natural, unprocessed foods, were also less likely to be consumed in small villages. Similar results were observed in the Dean and Sharkey study ${ }^{22}$. In their publication, the rural participants were used to eating fewer whole fruits than urban participants due to the distance of the retail food environment in rural settings. Additionally, the lower consumption of whole fruits was accompanied by limited variety and higher prices for whole fruits in retail sales in small villages. This occurs because whole fruits have shorter shelf lives and the consumers cannot store a lot of those, large distances to the retail outlets lead to people from small villages consuming fewer whole fruits and consequently the lower consumption contributes to a reduction in the variety and increased prices for whole fruits, as a vicious circle. 


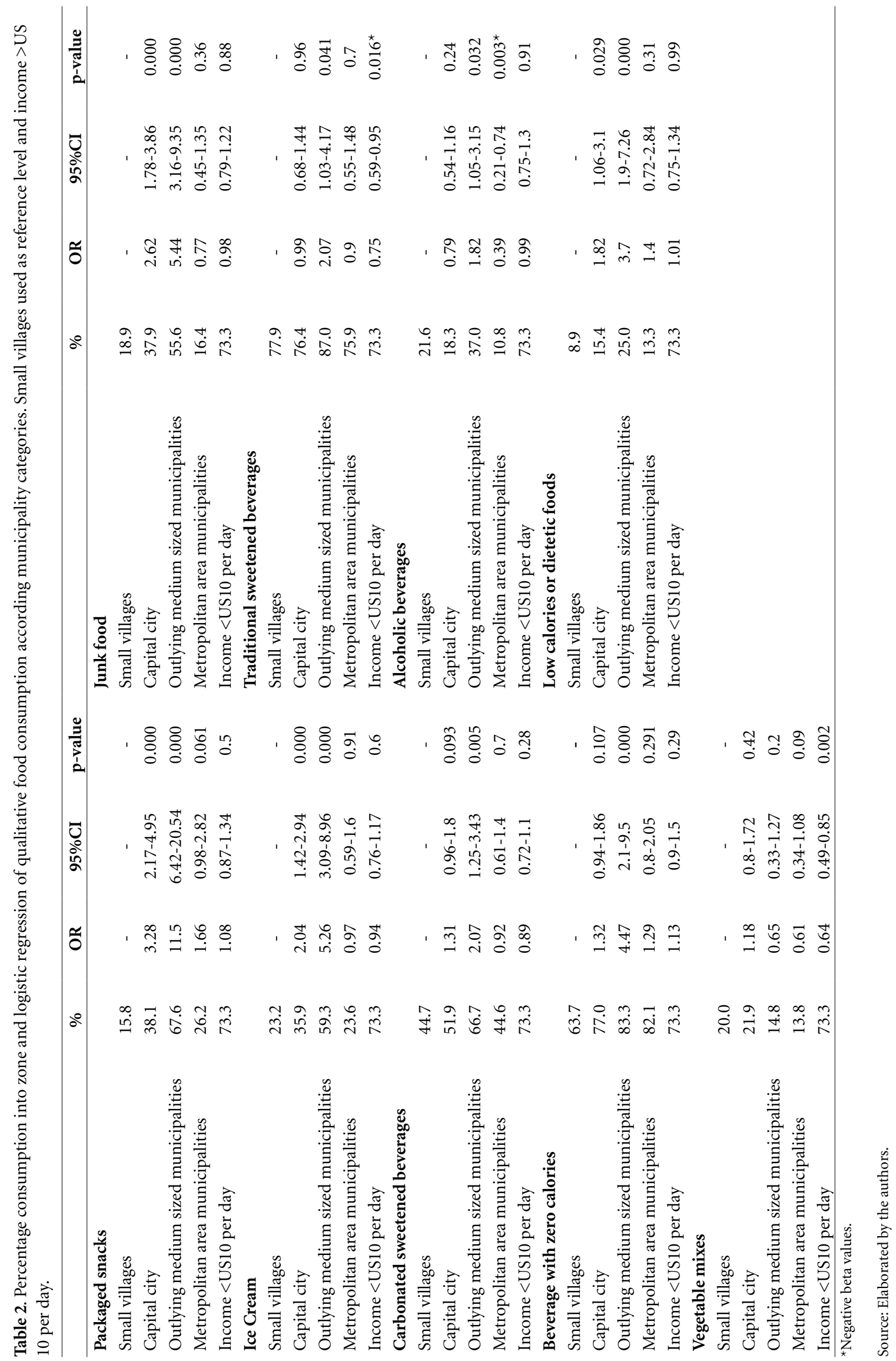




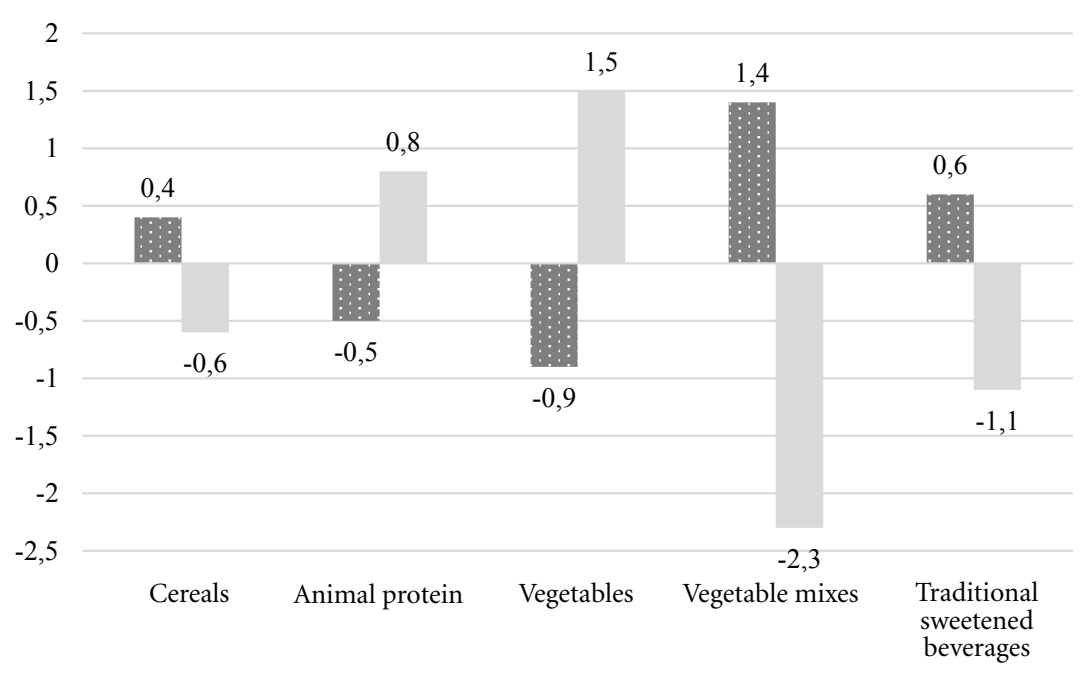

- Income $<$ US10 per day Income $>$ US10 per day

Figure 2. Differences in expected consumption frequencies.

Source: Elaborated by the authors.

The groups of packaged snacks, junk food, ice cream and low calories or dietetic foods were less likely to be consumed in small villages than in the Capital city and outlying medium-sized municipalities. It can also be associated with urbanization in these countries ${ }^{22}$ and the outlying medium-sized municipalities already present higher than likely consumption of those groups of processed foods.

The cereal group showed less likelihood of consumption in small villages than all other municipality categories. Cereals continue to remain by far the most important food source in the world. Their contribution to energy intake varies markedly between developing and industrial countries $^{22}$. In low and middle-income countries such as in Africa and parts of Asia, cereals can contribute to as much as 70 per cent of energy intake, while in industrial countries, for example, the UK, they provide approximately 30 per cent of energy intake. Projecting to 2050, it is expected that the share of cereals in calories for food use will continue to decline slowly from 49 per cent in 2030 to 46 per cent in $2050^{23}$.

Additionally, it was observed to be more likely to consume animal protein in metropolitan-area municipalities compared to small villages. One of the major consequences from a nutrition perspective of urbanization is a profound shift towards higher food energy, more fats and oils and more animal protein from meat. Data from the China Health and Nutrition Survey, which found an increase in the consumption of animal products, observed that this increase was higher for urban residents compared with those living in the countryside ${ }^{24}$.

It was observed that the consumption of milk was less likely in small villages than metropolitan-area municipalities, but without any notable differences when compared to the capital city and outlying medium-sized municipalities. In Brazil, low-priced milk became available to all economic levels because of supermarkets ${ }^{21}$, it can also help people from metropolitan-area municipalities have more access to this food. It is relevant to observe that all municipalities show milk consumption higher than $70 \%$.

Our findings corroborate the results from other studies about animal protein and vegetable consumption according to income. Those food groups used to be less consumed by people who have lower incomes. Animal protein and vegetables are often more expensive and less available in lower-income neighborhoods when compared with processed foods ${ }^{25,26}$. At the same time between people who have lower incomes, cereals, traditional sweetened beverages and vegetable mixes used to be higher. This can be explained because cereals contribute to energy intake in higher proportions among people with lower in- 
comes $^{24}$, vegetable mixes use to be distributed by social programs in Colombia to people with low incomes and traditional sweetened beverages are cheaper options of consumption.

There are important food consumption differences between small villages, metropolitan-area municipalities, outlying medium-sized municipalities and the capital city. These findings showed there is a spatial influence on food consumption in Colombia. As a spatial perspective allows for establishing barriers or enabling factors of a profile of consumption. This consumption can be protective or a predictor of non-communicable diseases, increasing health inequities among populations ${ }^{27}$. This study showed that in small villages there is less likelihood to consume a large variety of food. On the one hand, there is less likelihood to consume processed and ultra-processed food (such as dairy, processed meat, sugar, packaged snacks, ice cream, beverages with zero calories and low calorie or dietetic foods), which is positive for the consumption profile. But on the other hand, there is also less likelihood to consume whole fruits, which is negative for the consumption profile. So, this study corroborate that rural area residents have lower income and that it influences the kind of food consumption resulting in consumption of less variety of food as well as observed by other studies ${ }^{11,28}$.

It is important to highlight that this study was done in households with a representative sample and had geographic localization of different kinds of food group consumption. There are no reports of similar studies in Colombia. However, this study did evaluate the food consumption of one day, for this reason it was studied usual food consumption. In spite of, in all the studied areas there are establishments and food trading systems, this study did not describe them. Future studies that assess food consumption frequency in these populations and its association with spatial location of all kinds of food sellers/distributor are recommended.

\section{Collaborations}

DEF Rodriguez worked on conceptualization, data curation, formal analysis, investigation, methodology, project administration, resources, supervision, validation, writing-original draft, writing-review and editing. ML Moraes worked on data curation, formal analysis, investigation, methodology, writing-review and editing.

\section{References}

1. Popkin BM. An overview on the nutrition transition and its health implications: the Bellagio meeting. $\mathrm{Pu}$ blic Health Nutr 2002; 5(1A):93-103.

2. Popkin BM. Global nutrition dynamics: the world is shifting rapidly toward a diet linked with noncommunicable diseases. Am J Clin Nutr 2006; 84(2):289-298.

3. Monteiro CA, Cannon G, Levy RB, Claro RM, Moubarac J-C. The Food System. Ultra processing: The big issue for nutrition, disease, health, well-being. Position paper 2. World Nutrition 2012; 3(12):527-569.

4. Monteiro CA, Cannon G, Levy RB. Food classification NOVA: The star shines bright. World Nutrition 2016; 7(1-3):28-38

5. World Health Organization (WHO). Non-communicable diseases [Internet]. [acessado 2018 jul 1]. Disponível em: http://www.who.int/mediacentre/factsheets/ fs355/es/.

6. Moore LV, Diez Roux AV, Nettleton JA, Jacobs DR Jr. Associations of the Local Food Environment with Diet Quality - A Comparison of Assessments based on Surveys and Geographic Information Systems: The Multi-Ethnic Study of Atherosclerosis. Am J Epidemiol 2008; 167(8):917-924. 
7. Spence JC, Cutumisu N, Edwards J, Raine KD, Smoyer-Tomic K. Relation between local food environments and obesity among adults. BMC Public $\mathrm{He}$ alth 2009; 9:192.

8. Kelly B, Flood VM, Yeatman H. Measuring local food environments: an overview of available methods and measures. Health Place 2011; 17(6):1284-1293.

9. Menezes MC, Costa BV, Oliveira CD, Lopes AC. Local food environment and fruit and vegetable consumption: An ecological study. Prev Med Rep 2016; 5:13-20.

10. Liu GC, Wilson JS, Qi R, Ying J. Green neighborhoods, food retail and childhood overweight: Differences by population density. Am J Health Promot 2007; 21(Supl. 4):317-325.

11. Miller V, Yusuf S, Chow CK, Dehghan M, Corsi DJ, Lock K, Popkin B, Rangarajan S, Khatib R, Lear SA, Mony P, Kaur M, Mohan V, Vijayakumar K, Gupta R, Kruger A, Tsolekile L, Mohammadifard N, Rahman O, Rosengren A, Avezum A, Orlandini A, Ismail N, Lopez-Jaramillo P, Yusufali A, Karsidag K, Iqbal R, Chifamba J, Oakley SM, Ariffin F, Zatonska K, Poirier P, Wei L, Jian B, Hui C, Xu L, Xiulin B, Teo K, Mente A. Availability, Affordability, and Consumption of Fruits and Vegetables in 18 Countries Across Income Levels: Findings From the Prospective Urban Rural Epidemiology (PURE) Study. Lancet Glob Health 2016; 4(10):e695-e703.

12. Ruel MT, Garrett JL, Hawkes C, Cohen MJ. The food, fuel, and financial crises affect the urban and rural poor disproportionately: a review of the evidence. $J$ Nutr 2010; 140:170S-176S.

13. Reina-Usuga L, Jaimes WA, Suarez OE. Coordination on Agrifood Supply Chain. Int J Soc Behav Educ Econ Busi Industrial Engineering 2012; 6:2849-2853.

14. National Administrative Department of Statistics (DANE). Administrative Political Division of Colombia [Internet]. [acessado 2020 jul 1]. Disponível em: https://www.dane.gov.co.

15. Flórez CE, Villar L, Puerta N, Berrocal L. El proceso de envejecimiento de la población en Colombia: 19852050. In: Fedesarrollo y Fundación Saldarriaga Concha. Misión Colombia Envejece: cifras, retos y recomendaciones. Bogotá: Editorial Fundación Saldarriaga Concha; 2015. p. 14-80.

16. Bodor JN, Rose D, Farley TA, Swalm C, Scott SK. Neighbourhood fruit and vegetable availability and consumption: the role of small food stores in an urban environment. Public Health Nutr 2008; 11(4):413-420.

17. Moore LV, Diez Roux AV, Nettleton JA, Jacobs DR, Franco M. Fast-food consumption, diet quality, and neighborhood exposure to fast food: the multi-ethnic study of atherosclerosis. Am J Epidemiol 2009; 170(1):29-36.
18. Swinburn BA, Sacks G, Hall KD, McPherson K, Finegood DT, Moodie ML, Gortmaker SL. The global obesity pandemic: shaped by global drivers and local environments. Lancet 2011; 378(9793):804-814.

19. Popkin BM. Nutrition, agriculture and the global food system in low and middle income Countries. Food Policy 2014; 1(47):91-96.

20. Stuckler D, McKee M, Ebrahim S, Basu S. Manufacturing epidemics: the role of global producers in increased consumption of unhealthy commodities including processed foods, alcohol, and tobacco. PLoS Med 2012; 9(6):e1001235.

21. Kearney J. Food consumption trends and drivers. Phil Trans R Soc B 2010; 365:2793-2807.

22. Dean WR, Sharkey JR. Rural and urban differences in the associations between characteristics of the community food environment and fruit and vegetable intake. J Nutr Educ Behav 2011; 43(6):426-433.

23. Alexandratos N. World Agriculture: towards 2030/50, interim report. An FAO perspective. London: Earthscan, Rome: FAO; 2006

24. Zhai F, Wang H, Du S, He Y, Wang Z, Ge K, Popkin BM. Prospective study on nutrition transition in China. Nutr Rev 2009; 67(Supl. 1):S56-S61.

25. Guenther PM, Jensen HH, Batres-Marquez SP, Chen CF. Sociodemographic, knowledge, and attitudinal factors related to meat consumption in the United States. J Am Diet Assoc 2005; 105(8):1266-1274.

26. Connell CL, Zoellner JM, Yadrick MK, Chekuri SC, Crook LB, Bogle ML. Energy density, nutrient adequacy, and cost per serving can provide insight into food choices in the lower Mississippi Delta. J Nutr Educ Behav 2012; 44(2):148-153.

27. Forero DE, Rodríguez LS, Torres LM, Correa JC. Mobility Factors for Reducing Self-Reported Travel Times to Health Services. ACR Lat Am Adv 2017; 4:161-163.

28. Canuto R, Fanton M, Lira PIC. Iniquidades sociais no consumo alimentar no Brasil: uma revisão crítica dos inquéritos nacionais. Cien Saude Colet 2019; 24(9):3193-3212.

Article submitted 16/04/2019

Approved 19/10/2020

Final version submitted 21/10/2020

Chief editors: Romeu Gomes, Antônio Augusto Moura da Silva 